\title{
AN OVERVIEW OF ANGEL INVESTOR ECOSYSTEM
}

\section{DOI: 10.17261/Pressacademia.2021.1506 \\ PAP- V.14-2021(32)-p.128-129}

Dilek Teker ${ }^{1}$, Suat Teker ${ }^{2}$, Emre Orendil ${ }^{3}$

${ }^{1}$ Isik University, Department of Business, Sile Campus, Istanbul, Turkey. dilek.teker@isikun.edu.tr, ORCID: 0000-0002-3893-4015

${ }^{2}$ Isik University, Department of Business, Sile Campus, Istanbul, Turkey. suat.teker@isikun.edu.tr, ORCID: 0000-0002-7981-3121

${ }^{3}$ ssik University, Department of Business, Sile Campus, Istanbul, Turkey. emre.orendil@isikun.edu.tr, ORCID: 0000-0002-1924-8255

To cite this document

Teker, D., Teker, S., Orendil, E., (2021). An overview of angel investor ecosystem. PressAcademia Procedia (PAP), 14, $128-129$.

Permanent link to this document: http://doi.org/10.17261/Pressacademia.2021

Copyright: Published by PressAcademia and limited licensed re-use rights only.

\begin{abstract}
Purpose - The dynamics of the startup ecosystem exhibit variety from a country to another. A similar alteration applies for the characteristics of angel investors as they are an integral part of the startup ecosystem. Thus, it is required to have a closer look to the most recent local statistics to understand how the trends are swiftly changing in Turkey. This study distinguishes itself from the majority of the literature that it comes with suggestions for improving particularly the Turkish angel investor ecosystem.

Methodology - In the study, a comprehensive literature review is conducted to learn about the current circumstances of the European angel investor ecosystem and have a deep understanding about the Turkish angel investor ecosystem so that further improvements could be developed.

Findings - At the end of the literature review, seven major points open for the improvement of Turkish angel investor ecosystem are spotted. The issues present in the ecosystem such as the absence of strong connection among angel investors, the shortfall of angel investors' skills in certain fields, the insufficient technical knowledge of some entrepreneurs, the reservations caused by geographical remoteness, the underrepresentation of female angel investor, the lack of knowledge about the benefits of angel investing to both parties, the hardships in reaching out to early adopters are of utmost importance to be addressed.

Conclusion - In angel investing context, Turkey has a significant potential to be uncovered but needs to resolve the mentioned issues. It requires notable attention both from public and private sectors. This aim could be achieved through facilitating the networking practices among angel investors, nourishing the soft skills of angel investors, encouraging knowledge sharing, benefiting technological advancements to eliminate the problems caused by geographical remoteness, incentivizing participation of more female angel investors, raising awareness about the possible benefits of angel investment to both sides, and easing the access to early adopters.
\end{abstract}

Keywords: Angel investors, startup ecosystem, Turkish angel investor ecosystem, business angel networks, entrepreneurship. JEL Codes: M10, M12, M20

\section{REFERENCES}

Altuntaş, B., (2016). Early Stage Investment in Europe Today - What Incentives Do Business Angels Need?

Bammens, Y. and Collewaert, V., (2012). Trust between entrepreneurs and angel investors. Journal of Management, 40(7), 1980-2008.

Ding, Z., Sun, S. and Au, K., (2014). Angel investors' selection criteria: A comparative institutional perspective. Asia Pacific Journal of Management, 31(3), 705-731.

Dursun, E., Tekin, F. and Karaosmanoglu, A., (2017). Functioning of angel investor ecosystem in turkey: a study on aegean region angel investors. European Journal of Multidisciplinary Studies, 4(1), 32-42.

EBAN, (2020). EBAN Statistics Compendium 2019. Bruxelles.

Eban.org. (2021). Angel Investing Explained - EBAN. [online] Available at: <https://www.eban.org/angel-investing-explained/> [Accessed 25 October 2021]. 
Elvan, L., (2020). World Congress of the World Business Angel Investment Forum.

European Investment Fund - TTA Turkey, (2018). Entrepreneurship \& Technology Commercialization Report 2017: Global Trends and Specific Look at Turkey.

Ibrahim, D., (2008). The (not so) puzzling behavior of angel investors. Vanderbilt Law Review, 61(Arizona Legal Studies Discussion Paper No. 07-16), 1405-1416.

Kayahan, D., (2020). Challenges and Opportunities of Developing Startup Ecosystems: Central and Eastern Europe and.... [online] Medium. Available at: <https://medium.com/startup-intellect/challenges-and-opportunities-of-developing-startup-ecosystems-central-and-easterneurope-and-759f77a0b1aa> [Accessed 30 October 2021]

Lerner, J., (2000). A brief review of venture capital and private equity: a casebook. Toronto: John Wiley \& Sons.

Mason, C., (2006). Informal sources of venture finance. In: S. Parker, ed., The life cycle of entrepreneurial ventures. New York: Springer, 259-299.

Mason, C. and Stark, M., (2004). What do Investors Look for in a Business Plan?. International Small Business Journal: Researching Entrepreneurship, 22(3), 227-248.

Mason, C. and Harrison, R., (1994). The informal venture capital market in the UK. In: A. Hughes and D. Storey, ed., Financing Small Firms. London: Routledge, 64-111.

Mitteness, C., Sudek, R. and Cardon, M., (2012). Angel investor characteristics that determine whether perceived passion leads to higher evaluations of funding potential. Journal of Business Venturing, 27(5), 592-606.

Morrissette, S., (2007). A profile of angel investors. The Journal of Private Equity, 10(3), 52-66.

Presidency of the Republic of Turkey Investment Office, (2021). Turkey Destination for Early Stage Investments.

Sohl, J., (2021). The Angel Market in 2020: Return of the Seed and Start-Up Stage Market for Angels. Center for Venture Research,

Startup Basics. (2019). Everything you need to know about startup funding. [online] Available at: <https://startupbasics.com/startupfunding/> [Accessed 27 October 2021].

Startups Watch, (2021). Turkish Startup Ecosystem Quarterly Report - Q3 2021

Startups Watch and Presidency of the Republic of Turkey Investment Office, (2021). The State of Turkish Startup Ecosystem 2020.

UK Business Angels Association. (2021). Services for Entrepreneurs. [online] Available at:

<http://www.ukbusinessangelsassociation.org.uk/services-for-entrepreneurs> [Accessed 31 October 2021]

UNH Today. (2021). UNH finds angel investor market on the rise in 2020. [online] Available at:

<https://www.unh.edu/unhtoday/news/release/2021/05/19/unh-finds-angel-investor-market-rise-2020> [Accessed 31 October 2021].

Yeniova Saylak, G., (2020). Meleklerin 2020 planları. [online] Ekonomist. Available at: <https://www.ekonomist.com.tr/kapak-

konusu/meleklerin-2020-planlari.html> [Accessed 31 October 2021]. 